\begin{tabular}{|c|c|}
\hline Title & Nucleophilic Borylation of Benzyl Halides with Bis(pinacolato)diboron Catalyzed by Palladium(0) Complexes \\
\hline Author(s) & Ishiyama, T atsuo; O ohashi, Zengo; A hiko, Taka aki; Miyaura, Norio \\
\hline Citation & $\begin{array}{l}\text { Chemistry Letters, 31(8), 780-781 } \\
\text { https://doi.org/10.1246/cl.2002.780 }\end{array}$ \\
\hline Issue Date & $2002-08-05$ \\
\hline Doc URL & http://hdl.handle.net/2115/56196 \\
\hline Tyре & article (author version) \\
\hline File Information & (30) B-B + X-Benzyl (Com).pdf \\
\hline
\end{tabular}

Instructions for use 


\section{Nucleophilic Borylation of Benzyl Halides with Bis(pinacolato)diboron Catalyzed by Palladium(0) Complexes}

Tatsuo Ishiyama, ${ }^{*}$ Zengo Oohashi, Taka-aki Ahiko, and Norio Miyaura*

Division of Molecular Chemistry, Graduate School of Engineering, Hokkaido University, Sapporo 060-8628

(Received April 30, 2002; CL-020374)

Nucleophilic borylation of benzyl halides with bis(pinacolato)diboron in the presence of KOAc in toluene was effectively catalyzed by a palladium complex generated in situ from $\mathrm{Pd}(\mathrm{dba})_{2}$ and $\left(4-\mathrm{MeOC}_{6} \mathrm{H}_{4}\right)_{3} \mathrm{P}$, giving the corresponding pinacol benzylboronates in high yields.

Benzylboron compounds are useful synthetic intermediates, ${ }^{1}$ potential chiral Lewis acids, ${ }^{2}$ and potential ${ }^{10} \mathrm{~B}$ carriers for boron neutron capture therapy, ${ }^{3}$ which have been prepared by catalytic hydroboration of styrenes, ${ }^{4}$ transmetalation of benzylmetals to $\mathrm{BX}_{3}{ }^{5}$ homologation of arylboranes, ${ }^{6}$ or cross-coupling of haloarenes with borylmethylzinc reagents. ${ }^{7}$ Nucleophilic borylation of benzyl electrophiles would also provide an efficient and convenient route to benzylboron compounds; however, the lack of suitable boron nucleophiles has limited this protocol. Recently, we found that (alkoxo)diborons can undergo transmetalation with organo(oxo)palladium(II) complexes, thus allowing the cross-coupling reactions of (alkoxo)diborons with aryl, ${ }^{8}$ vinyl, ${ }^{9}$ and ally ${ }^{10}$ electrophiles in the presence of a palladium catalyst and a base. ${ }^{11}$ We report herein the palladium-catalyzed nucleophilic borylation of benzyl halides (2) with bis(pinacolato)diboron ${ }^{12}\left(\operatorname{pin}_{2} \mathrm{~B}_{2}\right.$, pin $\left.=\mathrm{Me}_{4} \mathrm{C}_{2} \mathrm{O}_{2}\right)$ (1) to provide pinacol benzylboronates (3) in high yields (eq 1$).{ }^{13}$

The borylation of benzyl chloride $(1.0 \mathrm{mmol})$ with $\operatorname{pin}_{2} \mathrm{~B}_{2}$ $1(1.1 \mathrm{mmol})$ was carried out at $50{ }^{\circ} \mathrm{C}$ for $24 \mathrm{~h}$ by using $\operatorname{Pd}(\mathrm{dba})_{2}$ $(0.03 \mathrm{mmol})$ as a catalyst precursor to examine the effects of ligands $(0.06 \mathrm{mmol})$, bases $(1.5 \mathrm{mmol})$, and solvents $(6 \mathrm{ml})$ (Table 1). Although $\mathrm{Pd}(\mathrm{dba})_{2}$ itself did not catalyze the reaction in the presence of KOAc in toluene (Entry 1), addition of a (4- $\left.\mathrm{MeOC}_{6} \mathrm{H}_{4}\right)_{3} \mathrm{P}$ ligand successfully promoted the borylation to afford the expected pinacol benzylboronate in $85 \%$ yield (Entry 
2). The catalyst efficiency highly depends on the electron-donating ability of phosphine ligands. Use of electron-neutral or -poor triarylphosphines such as $\mathrm{Ph}_{3} \mathrm{P}$ and $\left(4-\mathrm{ClC}_{6} \mathrm{H}_{4}\right)_{3} \mathrm{P}$ resulted in significantly lower yields (Entries 3 and 4). Although dppf and $\mathrm{Ph}_{3} \mathrm{As}$ have been used successfully for the analogous borylation of aryl ${ }^{8 \mathrm{a}, \mathrm{b}}$ or allyl ${ }^{10}$ electrophiles, these ligands were not effective for that of benzyl halides (Entries 5 and 6). The superiority of the electron-rich phosphine, $\left(4-\mathrm{MeOC}_{6} \mathrm{H}_{4}\right)_{3} \mathrm{P}$, prompted us to examine trialkylphosphines; however, $\left(c-\mathrm{C}_{6} \mathrm{H}_{11}\right)_{3} \mathrm{P}$ complexes ${ }^{8 \mathrm{c}}$ failed to catalyze the reaction probably due to their decomposition yielding phosphonium salts of benzyl chloride (Entry 7). KOAc was recognized to be the best base. Changing the base to an inorganic or weaker base such as $\mathrm{K}_{3} \mathrm{PO}_{4}$ and $\mathrm{KO}_{2} \mathrm{CCF}_{3}$ remarkably slowed down the reaction (Entries 8 and 9). As for solvents, non-polar ones such as toluene gave the best results. Use of polar solvents such as DMSO resulted in the formation of benzyl acetate (ca. $40 \%$ ) by the direct reaction of benzyl chloride with KOAc (Entry 10).

The synthesis of pinacol benzylboronates 3 by the reaction between $\operatorname{pin}_{2} B_{2} 1$ and representative benzyl halides 2 in the presence of a $\mathrm{Pd}(\mathrm{dba})_{2}-2\left(4-\mathrm{MeOC}_{6} \mathrm{H}_{4}\right)_{3} \mathrm{P}$ catalyst and a $\mathrm{KOAc}$ base in toluene is summarized in Table 2. ${ }^{14}$ The protocol is applicable not only to chlorides but also to bromides, providing variously functionalized $\mathbf{3}$ in high yields. The reaction smoothly proceeded at $50{ }^{\circ} \mathrm{C}$ for $\mathbf{2}$ having an electron-withdrawing substituent at the para position (Entries 1-4), whereas those having a donating group required heating to $80{ }^{\circ} \mathrm{C}$ (Entries 6 and 7). Either an electron-withdrawing or -donating substituent at the ortho position decelerated the reaction because of steric hindrance (Entries 8 and 9), while 1-(chloromethyl)naphthalene was smoothly borylated at $50{ }^{\circ} \mathrm{C}$ (Entry 10 ). The reaction is feasible with various functional groups such as $\mathrm{CN}$ and $\mathrm{CO}_{2} \mathrm{Me}$ which should be protected in the synthesis from benzyllithium or -magnesium reagents (Entries 1 and 3). ${ }^{5}$ All attempts at the borylation of 1-chloro-1-phenylpropane were unsuccessful probably due to its slow oxidative addition to the palladium(0) complex.

A one-pot synthesis of bis(borylmethyl)benzene via the sequential double borylation is shown in eq 2 . The reaction of $\operatorname{pin}_{2} B_{2} 1$ (2.2 equiv) with 1,4-bis(chloromethyl)benzene (1.0 equiv) at $80{ }^{\circ} \mathrm{C}$ in the presence of the palladium catalyst $(6$ mol\%) and KOAc (3.0 equiv) in toluene $(6 \mathrm{ml})$ gave the corresponding diborylated product in $61 \%$ yield.

In summary, the nucleophilic borylation of benzyl halides with bis(pinacolato)diboron is effectively catalyzed by a $\mathrm{Pd}(\mathrm{dba})_{2}-2\left(4-\mathrm{MeOC}_{6} \mathrm{H}_{4}\right)_{3} \mathrm{P}$ catalyst in the presence of KOAc in 
toluene. The reaction provides an efficient and convenient method for the synthesis of a wide variety of benzylboronates.

\section{References and Notes}

1 For a review, see: D. S. Matteson, "Stereodirected Synthesis with Organoboranes," Springer-Verlag, Berlin (1995).

2 U.-M. Gross, M. Bartels, and D. Kaufmann, J. Organomet. Chem., 344, 277 (1988).

3 For a review, see: A. H. Soloway, W. Tjarks, B. A. Barnum, F.-G. Rong, R. F. Barth, I. M. Codogni, and J. G. Wilson, Chem. Rev., 98, 1515 (1998).

4 For a review, see: I. Beletskaya and A. Pelter, Tetrahedron, 53, 4957 (1997).

5 For a review, see: A. Pelter, K. Smith, and H. C. Brown, "Borane Reagents," Academic Press, London (1988).

6 For a review, see: D. S. Matteson, J. Organomet. Chem., 581, 51 (1999).

7 G. Kanai, N. Miyaura, and A. Suzuki, Chem. Lett., 1993, 845.

8 a) T. Ishiyama, M. Murata, and N. Miyaura, J. Org. Chem., 60, 7508 (1995). b) T. Ishiyama, Y. Itoh, T. Kitano, and N. Miyaura, Tetrahedron Lett., 38, 3447 (1997). c) T. Ishiyama, K. Ishida, and N. Miyaura, Tetrahedron, 57, 9813 (2001).

9 K. Takahashi, J. Takagi, T. Ishiyama, and N. Miyaura, Chem. Lett., 2000, 126.

10 a) T. Ishiyama, T.-a. Ahiko, and N. Miyaura, Tetrahedron Lett., 37, 6889 (1996). b) T.-a. Ahiko, T. Ishiyama, and N. Miyaura, Chem. Lett., 1997, 811.

11 For reviews, see: a) T. Ishiyama and N. Miyaura, J. Synth. Org. Chem., Jpn., 57, 503 (1999). b) T. Ishiyama and N. Miyaura, J. Organomet. Chem., 611, 392 (2000).

12 a) H. Nöth, Z. Naturforsch., 39b, 1463 (1984). b) T. Ishiyama, M. Murata, T.-a. Ahiko, and N. Miyaura, Org. Synth., 77, 176 (2000).

13 Z. Oohashi, T.-a. Ahiko, T. Ishiyama, and N. Miyaura, 76th Annual Meeting of Chemical Society of Japan, Yokohama, March 1999, Abstr., No. 4B702. Similar borylation with pinacolborane was also reported: M. Murata, T. Oyama, S. Watanabe, and Y. Masuda, 77th Annual Meeting of Chemical Society of Japan, Sapporo, September 1999, Abstr., No. 3B602.

$14 \mathrm{~A}$ representative procedure for 3 ( $\left.\operatorname{pinBCH}_{2} \mathrm{Ph}\right)$ : A flask containing $\mathrm{Pd}(\mathrm{dba})_{2}(0.03 \mathrm{mmol}),\left(4-\mathrm{MeOC}_{6} \mathrm{H}_{4}\right)_{3} \mathrm{P} \quad(0.06$ $\mathrm{mmol}), \operatorname{pin}_{2} \mathrm{~B}_{2} 1$ (1.1 mmol), and KOAc $(1.5 \mathrm{mmol})$ was flushed with nitrogen, and then charged with toluene $(6 \mathrm{ml})$ and benzyl chloride $(1.0 \mathrm{mmol})$. The mixture was stirred at 
$50{ }^{\circ} \mathrm{C}$ for $24 \mathrm{~h}$. The product was isolated by Kugelrohr distillation to give an analytically pure sample: ${ }^{1} \mathrm{H}$ NMR $\left(400 \mathrm{MHz}, \mathrm{CDCl}_{3}, \mathrm{TMS}\right) \delta 1.23(\mathrm{~s}, 12 \mathrm{H}), 2.29(\mathrm{~s}, 2 \mathrm{H})$, 7.1-7.3 (m, $\left.5 \mathrm{H}) ;{ }^{13} \mathrm{C} \mathrm{NMR} \mathrm{(100} \mathrm{MHz,} \mathrm{CDCl}_{3}, \mathrm{TMS}\right) \delta$ $24.69,83.38,124.79,128.22,128.96,138.61$ (Due to quadrupolar relaxation, the carbon attached to the boron atom was not detected); HRMS $m / z$ Found: $\mathrm{M}^{+}, 218.1470$. Calcd for $\mathrm{C}_{13} \mathrm{H}_{19} \mathrm{BO}_{2}$ : 218.1478. 


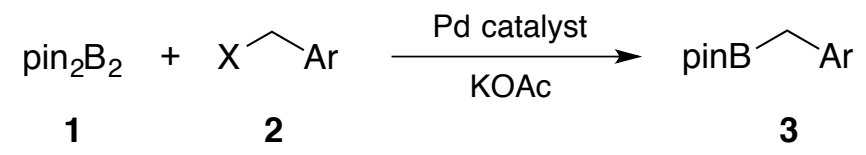

$21+\mathrm{Cl} \underset{\mathrm{Cl}}{\stackrel{\mathrm{Pd}(\mathrm{dba})_{2}-2\left(4-\mathrm{MeOC}_{6} \mathrm{H}_{4}\right)_{3} \mathrm{P}}{\mathrm{KOAc/toluene} / 80^{\circ} \mathrm{C} / 48 \mathrm{~h}}}$

(2.2 equiv) (1.0 equiv)

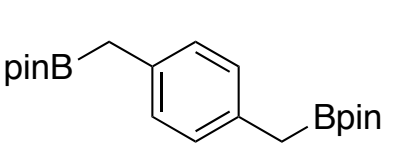

(2) 
Table 1. Reaction conditions for nucleophilic borylation of benzyl chloride with pin $_{2} \mathrm{~B}_{2} 1$ by using a $\mathrm{Pd}(\mathrm{dba})_{2}$ precatalyst $^{\mathrm{a}}$

\begin{tabular}{clllr}
\hline Entry & \multicolumn{1}{c}{ Ligand } & Base & Solvent & Yield/\% ${ }^{\mathrm{b}}$ \\
\hline 1 & none & $\mathrm{KOAc}$ & toluene & 0 \\
2 & $\left(4-\mathrm{MeOC}_{6} \mathrm{H}_{4}\right)_{3} \mathrm{P}$ & $\mathrm{KOAc}$ & toluene & 85 \\
3 & $\mathrm{Ph}_{3} \mathrm{P}$ & $\mathrm{KOAc}$ & toluene & 41 \\
4 & $\left(4-\mathrm{ClC}_{6} \mathrm{H}_{4}\right)_{3} \mathrm{P}$ & $\mathrm{KOAc}$ & toluene & 2 \\
5 & $\mathrm{dppf}^{\mathrm{C}}$ & $\mathrm{KOAc}$ & toluene & 59 \\
6 & $\mathrm{Ph}_{3} \mathrm{As}$ & $\mathrm{KOAc}$ & toluene & 23 \\
7 & $\left(c-\mathrm{C}_{6} \mathrm{H}_{11}\right)_{3} \mathrm{P}$ & $\mathrm{KOAc}$ & toluene & 0 \\
8 & $\left(4-\mathrm{MeOC}_{6} \mathrm{H}_{4}\right)_{3} \mathrm{P}$ & $\mathrm{K}_{3} \mathrm{PO}_{4}$ & toluene & 21 \\
9 & $\left(4-\mathrm{MeOC}_{6} \mathrm{H}_{4}\right)_{3} \mathrm{P}$ & $\mathrm{KO}_{2} \mathrm{CCF}_{3}$ & toluene & 6 \\
10 & $\left(4-\mathrm{MeOC}_{6} \mathrm{H}_{4}\right)_{3} \mathrm{P}$ & $\mathrm{KOAc}^{2}$ & DMSO & 50 \\
\hline
\end{tabular}

${ }^{\mathrm{a}} \mathrm{A}$ mixture of $\operatorname{pin}_{2} \mathrm{~B}_{2} \mathbf{1}(1.1 \mathrm{mmol})$, benzyl chloride $(1.0 \mathrm{mmol}), \mathrm{Pd}(\mathrm{dba})_{2}$ (0.03 mmol), a ligand $(0.06 \mathrm{mmol})$, a base $(1.5 \mathrm{mmol})$, and a solvent $(6 \mathrm{ml})$ was stirred at $50{ }^{\circ} \mathrm{C}$ for $24 \mathrm{~h}$. ${ }^{\mathrm{b}} \mathrm{GLC}$ yields based on benzyl chloride. ${ }^{c} 1,1$ '-Bis(diphenylphosphino)ferrocene $(0.03 \mathrm{mmol})$ was used. 
Table 2. Synthesis of pinacol benzylboronates (eq 1) ${ }^{\mathrm{a}}$

Entry

${ }^{a}$ A mixture of $\operatorname{pin}_{2} \mathrm{~B}_{2} \mathbf{1}(1.1 \mathrm{mmol})$, a benzyl halide $2(1.0 \mathrm{mmol})$, $\mathrm{Pd}(\mathrm{dba})_{2}(0.03 \mathrm{mmol}),\left(4-\mathrm{MeOC}_{6} \mathrm{H}_{4}\right)_{3} \mathrm{P}(0.06 \mathrm{mmol}), \mathrm{KOAc}(1.5$ $\mathrm{mmol})$, and toluene $(6 \mathrm{ml})$ was stirred for $24 \mathrm{~h}$ at the temperature shown in the Table. ${ }^{\mathrm{b}} \mathrm{GLC}$ yields based on benzyl halides $\mathbf{2}$. 